\title{
Integration of measurements and model simulations to characterize Eyjafjallajökull volcanic aerosols over south-eastern Italy
}

\author{
M. R. Perrone ${ }^{1}$, F. De Tomasi ${ }^{1}$, A. Stohl ${ }^{2}$, and N. I. Kristiansen ${ }^{2}$ \\ ${ }^{1}$ Physics Department, University of Salento, Lecce, Italy \\ ${ }^{2}$ NILU-Norwegian Institute for Air Research, Kjeller, Norway \\ Correspondence to: M. R. Perrone (perrone@le.infn.it)
}

Received: 21 May 2012 - Published in Atmos. Chem. Phys. Discuss.: 15 June 2012

Revised: 26 September 2012 - Accepted: 1 October 2012 - Published: 30 October 2012

\begin{abstract}
Volcanic aerosols resulting from the Eyjafjallajökull eruption were detected in south-eastern Italy from 20 to 22 April 2010, at a distance of approximately $4000 \mathrm{~km}$ from the volcano, and have been characterized by lidar, sun/sky photometer, and surface in-situ measurements. Volcanic particles added to the pre-existing aerosol load and measurement data allow quantifying the impact of volcanic particles on the aerosol vertical distribution, lidar ratios, the aerosol size distribution, and the ground-level particulate-matter concentrations. Lidar measurements reveal that backscatter coefficients by volcanic particles were about one order of magnitude smaller over south-eastern Italy than over Central Europe. Mean lidar ratios at $355 \mathrm{~nm}$ were equal to $64 \pm 5 \mathrm{sr}$ inside the volcanic aerosol layer and were characterized by smaller values ( $47 \pm 2 \mathrm{sr}$ ) in the underlying layer on 20 April, 19:30 UTC. Lidar ratios and their dependence with the height reduced in the following days, mainly because of the variability of the volcanic particle contributions. Size distributions from sun/sky photometer measurements reveal the presence of volcanic particles with radii $r>0.5 \mu \mathrm{m}$ on 21 April and that the contribution of coarse volcanic particles increased from 20 to 22 April. The aerosol fine mode fraction from sun/sky photometer measurements varied between values of 0.85 and 0.94 on 20 April and decreased to values between 0.25 and 0.82 on 22 April. Surface measurements of particle size distributions were in good accordance with column averaged particle size distributions from sun/sky photometer measurements. $\mathrm{PM}_{1} / \mathrm{PM}_{2.5}$ mass concentration ratios of $0.69,0.66$, and 0.60 on 20,21, and 22 April, respectively, support the increase of super-micron particles at ground. Measurements from the Regional Air Quality Agency show that $\mathrm{PM}_{10}$ mass concentrations on 20, 21,
\end{abstract}

and 22 April 2010 were enhanced in the entire Apulia Region. More specifically, $\mathrm{PM}_{10}$ mass concentrations have on average increased over Apulia Region $22 \%, 50 \%$, and $28 \%$ on 20,21, and 22 April, respectively, compared to values on 19 April. Finally, the comparison of measurement data with numerical simulations by the FLEXPART dispersion model demonstrates the ability of FLEXPART to model the advection of the volcanic ash over the $4000 \mathrm{~km}$ from the Eyjafjallajökull volcano to Southern Italy.

\section{Introduction}

The eruption of the Eyjafjallajökull volcano in Iceland entered a phase of strong ash ejection to the atmosphere on 14 April 2010, which lasted for several days. During the initial explosive phase, the eruption ejected volcanic ash to altitudes as high as $10 \mathrm{~km}$ above sea level (a.s.l.), as reported by the Institute of Earth Sciences (IES, http://www.earthice.hi.is). The westerly winds over Iceland transported the volcanic emissions first toward northern Europe (starting with UK and Norway) (Petersen, 2010), and then towards Central and Southern Europe. Emeis et al. (2011) found from remote sensing data and numerical simulations that the first volcanic ash layer reached Germany on 16 April. The volcanic ash was detected in clear layers above Switzerland starting from 17 April (Bukowiecki et al., 2011), above southern Italy from 19 April (Madonna et al., 2010; Mona et al., 2012), and over Greece after 21 April (Papayannis et al., 2012). The spatiotemporal distribution of the volcanic ash over Europe has been investigated extensively by EARLINET, the European Aerosol Research LIdar NETwork, which performed almost

Published by Copernicus Publications on behalf of the European Geosciences Union. 
continuous measurements from 15 April to 22 May 2010 (e.g. Ansmann et al., 2010; Wiegner et al., 2012; Gasteiger et al., 2011; Groß et al., 2011; Mona et al., 2012; Papayannis et al., 2012). Lidar instruments are well suited to observe aerosol layers at higher altitudes and can provide information about their vertical structure and development with time. In addition to lidars, different ground-based, airborne and space-borne instruments have been used to characterize the physical and optical properties of the volcanic aerosols resulting from the Eyjfjallajökull eruption (e.g. Bukowiecki et al., 2011; Schäfer et al., 2011; Revuelta et al., 2012; Campanelli et al., 2012; Schumann et al., 2011, Toledano et al., 2012; Rossini et al., 2012).

This paper focuses firstly on the integration of different measurements techniques to characterize aged volcanic aerosols at Lecce $\left(40.4^{\circ} \mathrm{N} ; 18.1^{\circ} \mathrm{E}\right)$, in south-eastern Italy, approximately $4000 \mathrm{~km}$ away from the Eyjafjallajökull volcano. After advection over so long distances, the volcanic ash is highly dispersed and the particle surfaces can be modified by condensation and coagulation processes upon contact with atmospheric trace gases and aerosols (Langmann et al., 2012). Therefore, the use of different remote sensing and in-situ sampling devices to characterize aged volcanic particles represents one of the main objectives of this study. Lidar measurements performed within EARLINET captured the spatiotemporal evolution of the volcanic aerosol plume over Lecce. Sun/sky photometer measurements performed within AERONET (Holben et al., 1998) at the lidar site allowed studying the volcanic aerosol effects on the main column-averaged aerosol optical and microphysical properties. Surface in-situ measurements showed how the volcanic ash influenced the particle size distribution and impacted the mass concentration of $\mathrm{PM}_{1}$ and $\mathrm{PM}_{2.5}$ particles. Finally, insitu $\mathrm{SO}_{2}$ and $\mathrm{PM}_{10}$ measurements performed by the Regional Air Quality Agency (www.arpa.puglia.it/web/guest/qariainq) have been analyzed to study the impact of volcanic aerosols on regional air quality in the entire Apulia Region. Synoptic meteorological maps and analytical back trajectories have mainly been used to infer the advection of volcanic aerosols to the monitoring site. Aerosol observations performed thousands of kilometres away from source regions are also important for the validation of volcanic ash transport models. Therefore, measurement data have been compared with results from the dispersion model FLEXPART.

An overview of the instrumentation and a brief description of the FLEXPART dispersion model are given in Sect. 2. Results and discussion are reported in Sect. 3. Main conclusions and caveats are presented in Sect. 4.

\section{Instrumentation and FLEXPART model}

\subsection{Experimental devices}

Remote sensing and surface in-situ measurements were conducted at the Physics Department of the University of Salento $\left(40.4^{\circ} \mathrm{N} ; 18.1^{\circ} \mathrm{E}\right)$, which is located $6 \mathrm{~km}$ away from the town of Lecce, in south-eastern Italy, and approximately $4000 \mathrm{~km}$ away from Iceland. Measurements are regularly performed there with a Raman lidar identified as UNILE (UNIversity of LEcce) lidar. The lidar has been operative since the beginning of the European Aerosol Research LIdar NETwork (EARLINET) in May 2000 (Matthias et al., 2004) and nowadays employs an f/4 Newton telescope with a 30-cm-diameter mirror and a frequency-tripled Nd-YAG laser $(355 \mathrm{~nm})$ that delivers pulses of $\sim 350 \mathrm{~mJ}$ of energy at a repetition rate of $30 \mathrm{~Hz}$. The UNILE lidar has been designed to derive vertical profiles of aerosol extinction $(\alpha(z))$ and backscatter $(\beta(z))$ coefficients and lidar ratios $(\operatorname{LR}(z))$ during nighttime and aerosol backscatter coefficients during daytime at a wavelength of $355 \mathrm{~nm}$. Details on experimental apparatus and data analysis are reported in De Tomasi and Perrone (2003) and De Tomasi et al. (2003, 2006). The statistical uncertainties of $\beta(z)$ are calculated from the error propagation law by assuming a Poisson noise on the lidar signals. The aerosol extinction coefficient is calculated by a linear fit of the derivative of the logarithm of the nitrogen Raman signal with respect to the range (Ansmann et al., 1992), and its uncertainties are set as the uncertainties associated to the slope of the fitting straight lines. Lidar ratio $(\operatorname{LR}(z)=\alpha(z) /(\beta(z))$ uncertainties are calculated using standard propagation techniques (Bevington and Robinson, 2003). The lidar system is estimated to achieve full overlap between $0.3-0.5 \mathrm{~km}$ (Matthias et al., 2004).

An AERONET sun/sky radiometer has been operative at the lidar site since March 2003. AERONET is a federated international network of sun/sky radiometers established in 1993 (Holben et al., 1998). Data are publicly available online in near real-time mode (http://aeronet.gsfc.nasa.gov). The sun/sky radiometer measures direct sun radiance in eight spectral channels between 340 and $1020 \mathrm{~nm}$ (340, 380, 440, 500, 670, 870, 940 and $1020 \mathrm{~nm}$ ). Sky measurements are performed at $440,670,870$ and $1020 \mathrm{~nm}$ wavelengths through a wide range of scattering angles from the Sun (Holben et al., 1998). An automated cloud-screening algorithm (Smirnov et al., 2000) is applied to AOT direct-sun measurements. Aerosol microphysical parameters are retrieved from direct sun and diffuse sky radiance measurements by a flexible inversion algorithm, developed by Dubovik and King (2000). A discussion on the accuracy of individual retrievals was reported in Dubovik et al. (2000). Quality assured (automatically cloud cleared and manually inspected) level 2 AERONET data retrieved from measurements performed between 19 and 22 April 2010 were used in this study. 
For continuous aerosol size distribution measurements at about $10 \mathrm{~m}$ from the ground, a TSI Aerodynamic Particle Sizer (APS) 3321 with 51 channels of equal logarithmic width of 0.031 within the diameter size range of 0.54 $20.0 \mu \mathrm{m}$ was deployed. The APS measurements started on 21 April at midday. Particulate matter (PM) samples have also been collected at $\sim 10 \mathrm{~m}$ above the ground level (a.g.l.) with a low volume $\left(2.3 \mathrm{~m}^{3} \mathrm{~h}^{-1}\right)$ HYDRA-FAI dual sampler that allowed 24-h simultaneous collection of $\mathrm{PM}_{2.5}$ and $\mathrm{PM}_{1}$ samples on 47-mm-diameter preheated filters (PALLFLEX, Tissuquartz). The filters were conditioned for $48 \mathrm{~h}\left(25^{\circ} \mathrm{C}\right.$ and $50 \%$ humidity) before and after sampling, and PM mass concentrations were determined by the gravimetric method. Uncertainties of the mass concentrations are below $5 \%$.

\subsection{The FLEXPART dispersion model}

The Lagrangian particle dispersion model FLEXPART (Stohl et al., 1998, 2005) was used to simulate the transport of volcanic ash. FLEXPART was run in forward mode and driven with meteorological data from the European Centre for Medium-Range Weather Forecasts (ECMWF) analyses with $0.18^{\circ} \times 0.18^{\circ}$ horizontal resolution and 91 vertical model levels. The simulation accounted for gravitational particle settling as well as dry and wet deposition, but not for ash aggregation processes. Formation of sulphate particles was also not simulated. Ash emission rates as a function of time and height, determined previously using an inversion scheme that coupled a priori source information and FLEXPART model results with satellite data (Stohl et al., 2011), were used as a source term for this study. The ash particle size distribution included 25 particle size classes from 0.25 $250 \mu \mathrm{m}$ diameter. The model output had a horizontal resolution of $0.25^{\circ} \times 0.25^{\circ}$ and a vertical resolution of $250 \mathrm{~m}$.

\section{Results and discussion}

\subsection{The advection of volcanic aerosols to south-eastern Italy}

The synoptic meteorological situation on 14-15 April, with a high located south of Iceland and a trough over northern Scandinavia, favoured the transport of ash first over Norway and later over Southern England, Denmark and Central Europe (e.g. Peterson, 2010; Folch et al., 2012). Stagnant conditions over Central Europe during the following days favoured a long residence time of the ash over Europe, associated with slow subsidence of the ash layers and settling of larger particles. The situation changed on 20 April when north-westerly winds transported parts of the volcanic ash plume first over south-eastern Europe and then over Eastern Europe on 23 April (Fig. 1 of the paper by Folch et al., 2012). Eight-day analytical back trajectories from the Hybrid Single Particle Lagrangian Integrated Trajectory Model (HYSPLIT) (Draxler and Rolph, 2010) have been analyzed in this study to infer the arrival of volcanic particles over Lecce. We found that air masses from south-eastern $\mathrm{Eu}-$ rope and north-western Africa were mainly advected over south-eastern Italy up to $\sim 3 \mathrm{~km}$ a.s.l. on the diurnal hours of 19 April. Back trajectories with an origin over Central Europe arrived in south-eastern Italy up to $\sim 3 \mathrm{~km}$ a.s.l. on the morning of 20 April, in accordance with the synoptic meteorological situation (Folch et al., 2012). The arrival over the monitoring site of this study of air masses which had previously travelled across Iceland started on the afternoon of 20 April. Figure 1a shows the 8-day back trajectories ending at the Physics Department of the Salento University on 20 April at 18:00 UTC. The back trajectory ending at $\sim 0.5 \mathrm{~km}$ a.s.l. crossed Iceland before reaching the monitoring site. The back trajectories ending at $\sim 2$ and $3 \mathrm{~km}$ a.s.l. originated over Central Europe. However, they had then travelled over European regions known to have been affected by volcanic ash before reaching Lecce, and as a consequence may have been responsible for the advection of volcanic particles at altitudes larger than few kms a.s.l. Figure $1 \mathrm{~b}$ shows the pathway of the back trajectories arriving over Lecce on 21 April at 06:00 UTC. Both the $2 \mathrm{~km}$ - and the $3 \mathrm{~km}$-arrivalheight back trajectories had travelled across Iceland before reaching Lecce. Figure 1c and d shows the pathways of back trajectories arriving over Lecce on 21 April at 18:00 UTC and on 22 April at 12:00 UTC. Air masses from northern Europe at lower altitudes and from north-western Africa at higher altitudes were transported to Lecce on 23 April. Thus, the transport of volcanic particles to south-eastern Italy was most likely on 20, 21, and 22 April according to HYSPLIT back trajectories. Analytical back trajectories provided by NASA (http://croc.gsfc.nasa.gov/aeronet/index.html) for the monitoring site of this study, which are based on a kinetic trajectory analysis using NASA GMAO assimilated gridded data, were generally similar. It is also worth noting, that from 20 April, 21:00 UTC until 22 April, 03:09 UTC, volcanic particles were detected in the free troposphere at the CNR-IMAA Laboratory in Potenza $\left(40^{\circ} 36^{\prime} \mathrm{N}, 15^{\circ} 44^{\prime} \mathrm{E}\right.$, $760 \mathrm{~m}$ a.s.1.), which is $\sim 250 \mathrm{~km}$ away from the monitoring site of this study (Mona et al., 2012).

Plots of volcanic-ash column-integrated mass concentrations over Europe from FLEXPART (Fig. 2) confirm the advection of volcanic aerosol over southeastern Italy from 20 to 22 April. The green dot in Fig. 2 represents the lidar site. Simulated ash columnar mass concentrations at Lecce are higher than a few $\mathrm{mg} \mathrm{m}^{-2}$ after the afternoon of 20 April. They reach the highest values of nearly $200 \mathrm{mg} \mathrm{m}^{-2}$ during the night of 20/21 April and subsequently decrease to rather low levels in the afternoon of 22 April. Notice that even the largest ash column loadings over Lecce are about one order of magnitude lower compared to those simulated by FLEXPART over Central Europe on 16 April (Stohl et al., 2011). Thus, while some volcanic ash reached south-eastern Italy, it is much more diluted than earlier over Central Europe. Simulations of the Eyjafjallajökull volcanic ash dispersal over 

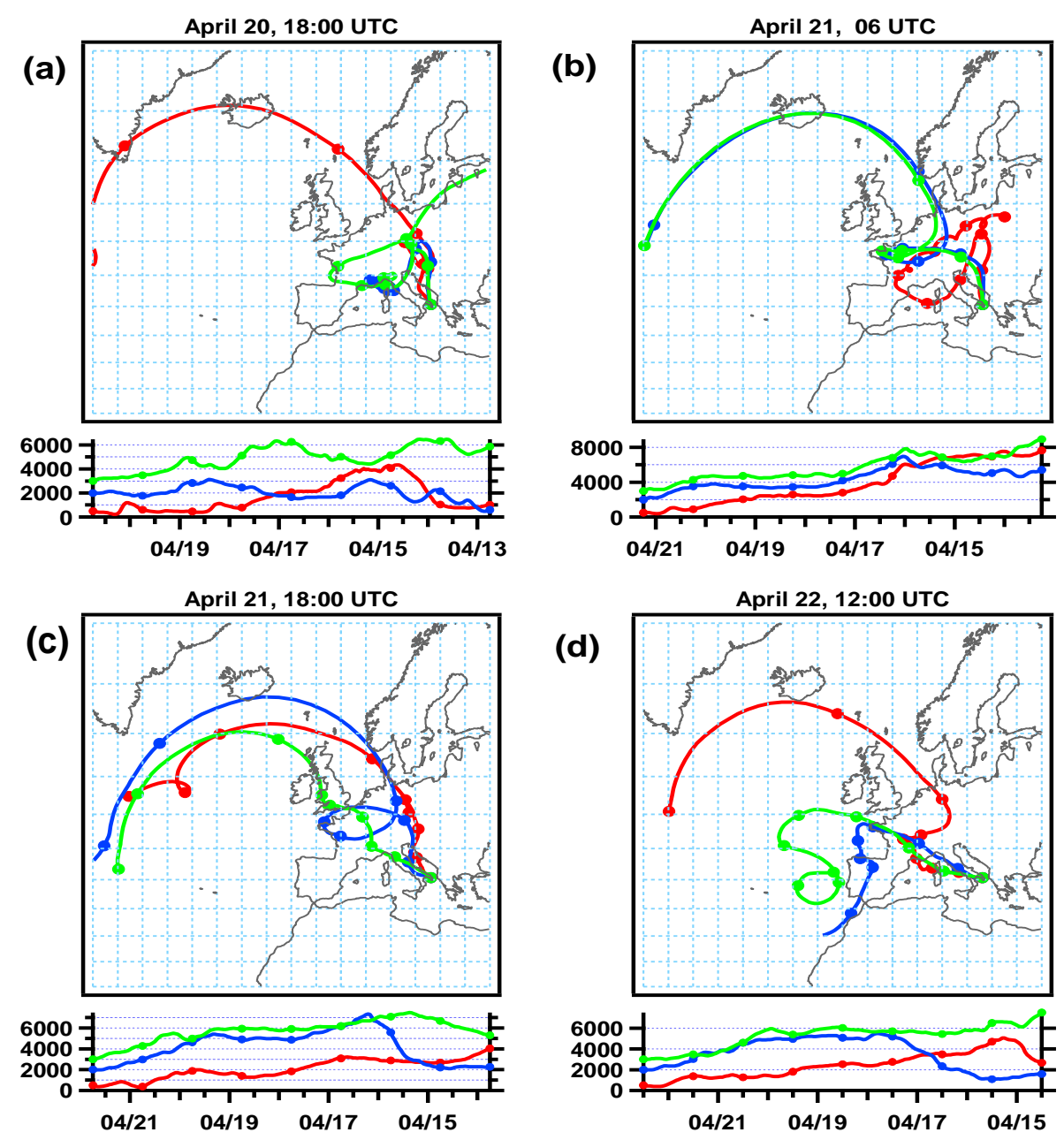

Fig. 1. 8-day back trajectories from the Hybrid Single Particle Lagrangian Integrated Trajectory Model (HYSPLIT) of air masses ending at the Physics Department of the Salento University, Lecce (Italy), (a) on 20 April at 18:00 UTC, (b) on 21 April at 06:00 UTC, (c) on 21 April at 18:00 UTC, and (d) on 22 April at 12:00 UTC.

Europe using COSMO-MUSCAT also revealed the advection of diluted ash over south-eastern Italy on 21 April (Fig. 4 of the paper by Heinold et al., 2012).

\subsection{UNILE lidar measurements}

Figure 3 (solid lines) shows the backscatter coefficient $(\beta)$ profiles at $355 \mathrm{~nm}$ retrieved from lidar measurements performed from 20 April until 22 April. $\beta$-profiles have been retrieved from one-hour-average lidar measurements. More specifically, the profile at 05:30 UTC was calculated by averaging lidar measurements from 05:00 to 06:00 UTC. Aerosol optical thicknesses (AOTs) at $355 \mathrm{~nm}$, calculated from lidar profiles, are also reported in each plot of Fig. 3. To this end, we have assumed that extinction profiles did not vary with altitude in the lowermost aerosol layer, whose height is of the order of the planetary boundary layer (PBL) height (De Tomasi and Perrone, 2006). Then, we can assume that aerosol particles are well mixed within the PBL.
Figure $3 \mathrm{a}$ shows that aerosol particles monitored by the lidar were mainly located below $3 \mathrm{~km}$ from the ground level at 05:30 UTC on 20 April. The aerosol-load-height increased with the time of day and the comparison of Fig. $3 a$ and $b$ shows that at 17:30 UTC, backscatter coefficients were characterized by larger values $\left(\cong 1.5 \mathrm{Mm}^{-1} \mathrm{sr}^{-1}\right)$ mainly within the $2.5-3.0 \mathrm{~km}$ altitude range. We believe that the advection of volcanic aerosol has likely contributed to the increase of $\beta$-values above $2.5 \mathrm{~km}$ a.s.l., in accordance with back trajectory pathways. The gradually descending layers of volcanic particles that were observed at the CNR-IMAA Laboratory (Mona et al., 2012) from 20 April, 21:00 UTC, and 21 April, 12:00 UTC, between about $4 \mathrm{~km}$ a.s.l. and the onset of the PBL, support this. Notice that the $\beta$-values at $1064 \mathrm{~nm}$ retrieved at the CNR-IMAA Laboratory varied within the $0.05-2.0 \mathrm{Mm}^{-1} \mathrm{sr}^{-1}$ range within volcanic ash layers. Extinction $(\alpha)$ and lidar ratio (LR) profiles retrieved at Lecce from nighttime Raman lidar measurements (De Tomasi et 
(a)

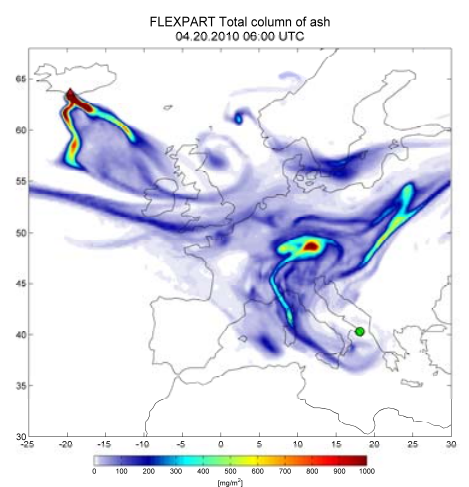

(c)

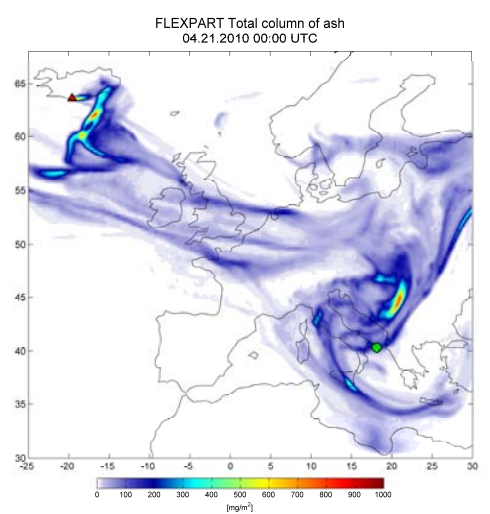

(e)

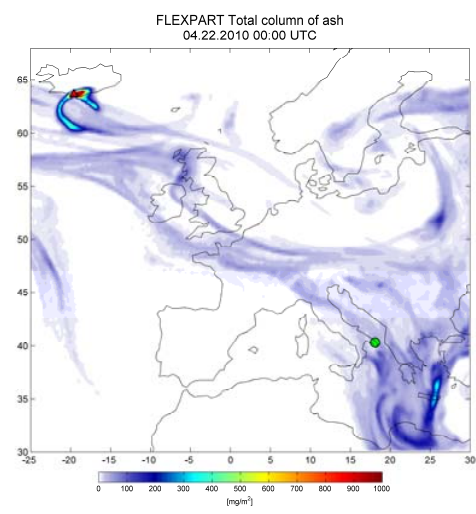

(b)
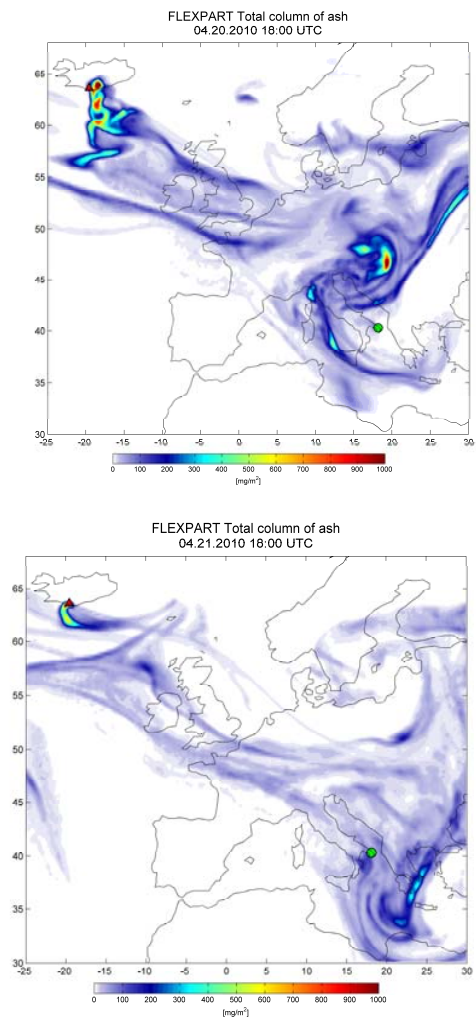

(d)

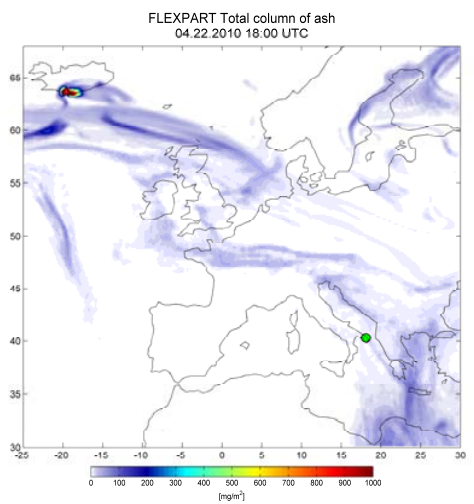

Fig. 2. FLEXPART simulations of the Eyjafjallajökull volcanic ash (total atmospheric columns in $\mathrm{mg} \mathrm{m}^{-2}$, integrated over all 25 particle size classes) on 20 April at (a) 06:00 UTC, (b) 18:00 UTC, (c) 24:00 UTC, on 21 April at (d) 18:00 UTC, (e) 24:00 UTC, and on 22 April at (f) 18:00 UTC. The green dot marks the monitoring site.

al., 2006) are plotted in Fig. 4. The lidar ratio profile at 19:30 UTC on 20 April (Fig. 4a, dots) allows inferring two main aerosol layers: one extends up to about $1.8 \mathrm{~km}$ a.s.l. and is characterized by LRs $=47 \pm 2 \mathrm{sr}$, and the other extends over the $2.1-3.3 \mathrm{~km}$ range and is characterized by lidar ratios spanning the 65-71 sr range (Table 1). The lower LR values retrieved up to $2 \mathrm{~km}$ a.s.l. (Fig. $4 \mathrm{a}$, dots) are affected by the contribution of pre-existing aerosol particles, which are not of volcanic origin. We believe that the larger LRs retrieved within the upper aerosol layer are likely due to the contribution of volcanic aerosol: air masses from Cen- tral European regions known to have been affected by volcanic ash arrived at Lecce at altitudes larger than $2 \mathrm{~km}$ a.s.l. on the evening of 20 April. Notice that Ansmann et al. (2010) found that the volcanic ash plume monitored on 16 April (14:15-15:30 UTC) at Leipzig (Germany) was characterized by lidar ratios at $355 \mathrm{~nm}$ of 55-65 sr (Table 1). Papayannis et al. (2012) found lidar ratios at $355 \mathrm{~nm}$ of $55-76 \mathrm{sr}$ in volcanic aerosol layers $2.0-4.8 \mathrm{~km}$ a.s.l. monitored over Greece and Turkey. Mean LR values at $355 \mathrm{~nm}$ retrieved at Lecce for different altitude ranges are compared in Table 1 with the corresponding ones retrieved at Potenza from 20 to 22 


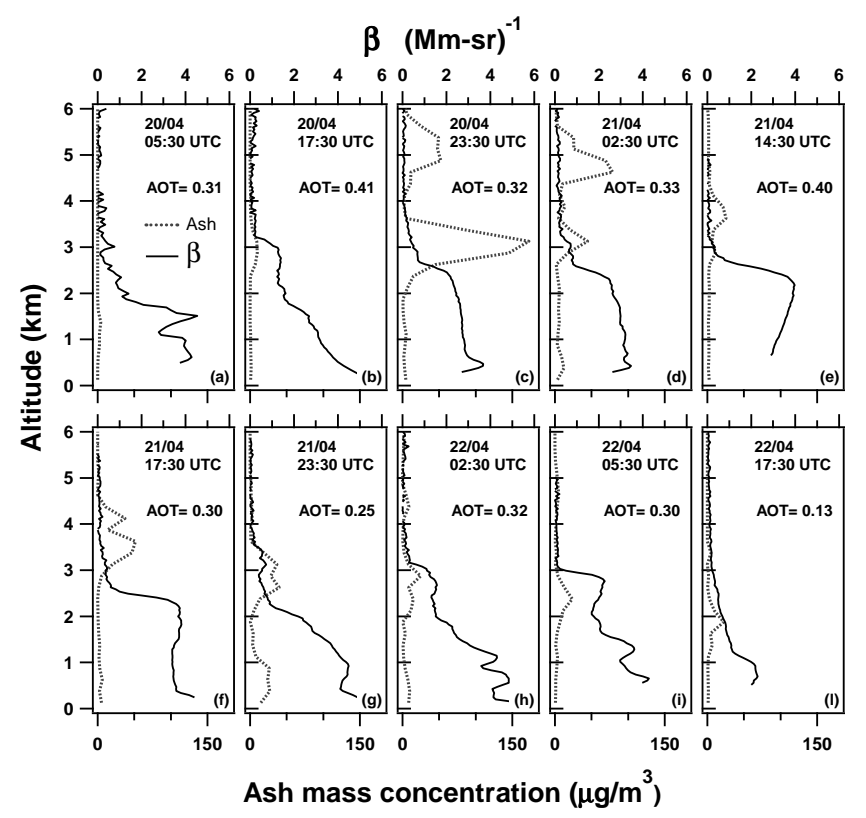

Fig. 3. Vertical profiles of the aerosol backscatter coefficient at $355 \mathrm{~nm}$ (solid line) and of the volcanic ash mass concentration simulated by FLEXPART (dotted line) at different hours on 20, 21, and 22 April 2010.

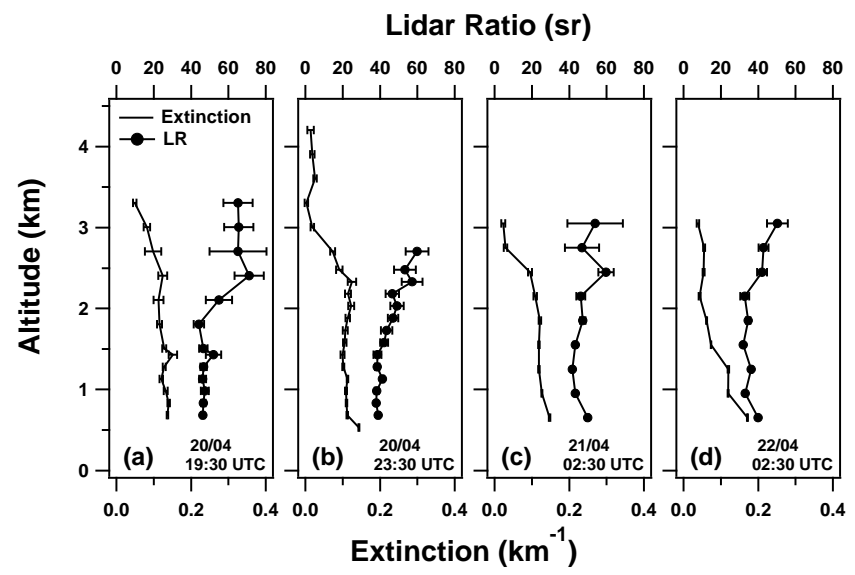

Fig. 4. Vertical profiles of the aerosol extinction coefficient (solid line) and of the lidar ratio (full dots) retrieved from nighttimes lidar measurements at different hours on 20, 21, and 22 April 2010.

April (Mona et al., 2012) and the one provided by Ansmann et al. (2010). It is worth noting that LR values retrieved at Lecce at 23:30 UTC on 20 April are in good accordance with the ones retrieved at Potenza within the same altitude range. The lidar measurements at 02:30 on 21 April (Fig. 4c, dots) shows that LR values were less dependent on altitude than for the earlier measurements (Table 1). The mixing of volcanic aerosols with underlying aerosol particles as a consequence of particle sedimentation, subsidence, and/or the spa-
Table 1. Mean values and standard deviations of the lidar ratios at $355 \mathrm{~nm}$ retrieved at Lecce, Potenza, and Leipzig on different days and hours and at different altitude ranges.

\begin{tabular}{lcl}
\hline $\begin{array}{l}\text { Time } \\
\text { (UTC) }\end{array}$ & $\begin{array}{c}\text { Altitude } \\
\text { (km a.s.1.) }\end{array}$ & $\begin{array}{l}\mathrm{LR}_{355 \mathrm{~nm}} \\
(\mathrm{sr})\end{array}$ \\
\hline $\begin{array}{l}\text { 16 April, 14:15-15:30 } \\
\text { Ansmann et al. (2010) }\end{array}$ & 2.5 .4 .0 & $60 \pm 5$ \\
\hline 20 April, 19:00-20:00 & $0.6-1.8$ & $47 \pm 2$ \\
& $2.1-3.3$ & $64 \pm 5$ \\
\hline 20 April, 23:00-24:00 & $0.7-1.9$ & $40 \pm 3$ \\
& $2.3-2.7$ & $57 \pm 3$ \\
\hline 20 April, 21:00-23:05 & $2.0-3.0$ & $42 \pm 2$ \\
Mona et al. (2012) & $3.1-4.0$ & $38 \pm 6$ \\
\hline 21 April, 02:00-03:00 & $0.6-2.1$ & $45 \pm 3$ \\
& $2.4-3.1$ & $53 \pm 6$ \\
\hline 22 April, 02:00-03:00 & $0.6-2.1$ & $35 \pm 3$ \\
\hline 21-22 April, 19:07-03.09 & $1.6-3.4$ & $80 \pm 12$ \\
Mona et al. (2012) & & \\
\hline
\end{tabular}

tiotemporal variability of the volcanic aerosol contribution were likely responsible for this result.

Aerosol particles up to about $4 \mathrm{~km}$ a.s.l. were detected by the lidar at 23:30 UTC on 20 April (Fig. 3c). The aerosol load and the maximum height where aerosols were detected by the lidar decreased with time on 21 April. These results are due to smaller contributions of both volcanic aerosols and non-volcanic particles. Aerosol particles were located up to $\sim 3.2 \mathrm{~km}$ a.s.l. and lidar ratios spanned the $32-50 \mathrm{sr}$ range at 02:30 UTC on 22 April (Figs. 3g and 4d). Significantly larger LRs were retrieved on 21-22 April, 19:07-03:09 at Potenza.

Figure 5 shows the time evolution from 20 to 22 April 2010 of the aerosol optical thickness at $355 \mathrm{~nm}$ (open dots) retrieved from lidar measurements. Notice that non-volcanic aerosols likely contributed to the rather high AOTs retrieved from lidar measurements performed during the daytime hours of 20 April, if we assume that the advection of volcanic particles over south-eastern Italy mainly occurred starting the evening of 20 April, in accordance with HYSPLIT backtrajectories. AOT values vary significantly with time: they reach a peak value at $\sim 15: 30$ UTC on 21 April, then decrease, and then a peak value is again observed at about 03:00 UTC on 22 April. The advection over the monitoring site of this study of an inhomogeneous cloud of volcanic particles was likely responsible for these results. In fact, Figs. 3 and 4 show that both the aerosol backscatter coefficient and lidar ratios varied with time and height from 20 to 22 April. 


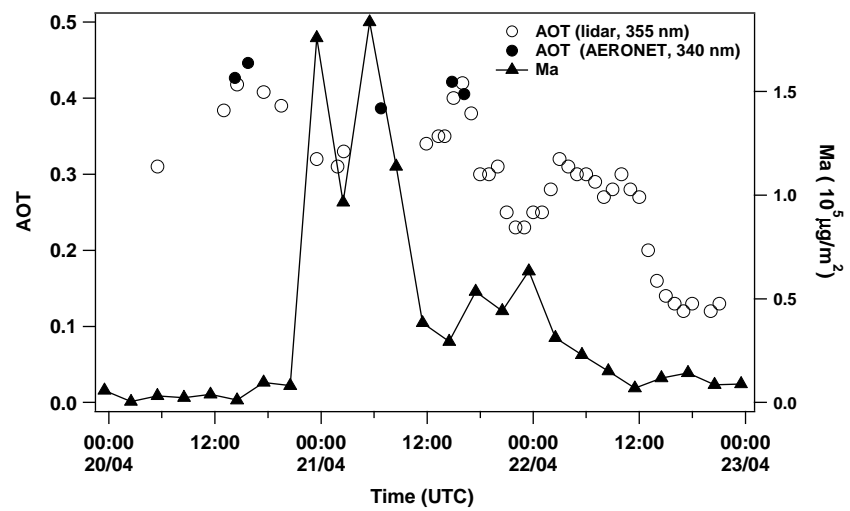

Fig. 5. Time series of the aerosol optical thickness (AOT) at $355 \mathrm{~nm}$ from lidar measurements (open dots) and of the ash total column (Ma) simulated by FLEXPART at the lidar site (full triangles). Full dots represent the aerosol optical thickness at $340 \mathrm{~nm}$ from AERONET sun/sky photometer measurements.

\subsection{AERONET sun/sky photometer measurements}

AERONET aerosol products (Version 2, Level 2 data) are lacking for the monitoring site of this study from 12 to 19 April. In addition, only some aerosol products are available from 14:15 UTC on 20 April until 16:11 UTC on 21 April. In particular, refractive index and single scattering albedo values have not been provided for these two days. The AERONET values of the AOT at $340 \mathrm{~nm}$ retrieved from sun/sky photometer measurements performed from 20 to 22 April 2010 are plotted in Fig. 5 (full circles). We observe that the few available AERONET-AOTs at $340 \mathrm{~nm}$ are in satisfactory agreement with lidar AOTs at $355 \mathrm{~nm}$. Figure 6 shows the evolution with time of the AOT at $500 \mathrm{~nm}$ (full dots) and the fine mode fraction $\eta$ (open triangles) from 20 to 22 April (Spectral Deconvolution Algorithm, Version 4.1, Level 2 data). $\eta$ represents the ratio of the AOT due to fine mode particles with a radius $r$ smaller than $0.4-0.5 \mu \mathrm{m}$, to the total AOT. Figure 6 shows that AOT $(500 \mathrm{~nm})$ values on average decrease from 20 to 22 April, in accordance with lidar-AOTs $(355 \mathrm{~nm}) .500 \mathrm{~nm}$-AOTs also vary significantly with time and reach a peak value at $\sim 15: 30$ UTC on 21 April, in accordance with lidar-AOTs (Fig. 5, open circles). The fine mode fraction decreases from 20 to 22 April (Fig. 6, open triangles), indicating that the contribution of coarse mode particles increases. The columnar volume size distribution profiles retrieved on 20 and 21 April from AERONET sun/sky photometer measurements are plotted in Fig. 7a and b. No data are available for 19 and 22 April. If we assume that the differences on the aerosol load monitored on 20 and 21 April are mainly due to the contribution of volcanic particles, we can use the differences between the volume size distribution retrieved on 21 April at 14:49 UTC $\left((\mathrm{d} V(r) / \mathrm{d} \ln r)_{\mathrm{A}}\right)$, and the one retrieved on 20 April at 14:15 UTC $\left((\mathrm{d} V(r) / \mathrm{d} \ln r)_{\mathrm{B}}\right)$, to determine the size distribution of volcanic aerosols on 21

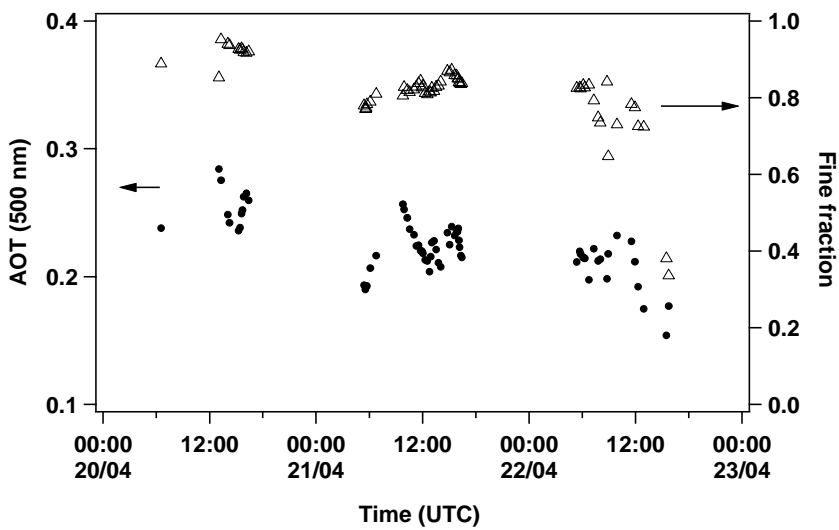

Fig. 6. Time evolution from 20 to 22 April 2010 of the aerosol optical thickness (AOT) at $500 \mathrm{~nm}$ (full dots) and of the fine mode fraction (open triangles) from AERONET sun/sky photometer measurements.

April, 14:49 UTC. Figure 8 (solid line) shows the mass size distribution calculated in accordance with the following relationship:

$\mathrm{d} M_{\mathrm{A}-\mathrm{B}} / \mathrm{d} \log (r)=\left((\mathrm{d} V(r) / \mathrm{d} \ln r)_{\mathrm{A}}-(\mathrm{d} V(r) / \mathrm{d} \ln r)_{\mathrm{B}}\right) \cdot \ln 10 \cdot \rho$,

where $\rho=3.0 \mathrm{~g} \mathrm{~cm}^{-3}$ represents the particle density for volcanic ash, according to Kristiansen et al. (2012). Positive $\mathrm{d} M_{\mathrm{A}-\mathrm{B}} / \mathrm{d} \log (r)$ values are found for the $0.05-0.11 \mu \mathrm{m}$ radius range and for radii $r>0.5 \mu \mathrm{m}$ (Fig. 8, solid line). While the difference for the small radii can be explained by the nucleation and subsequent growth of sulphate particles from volcanic $\mathrm{SO}_{2}$ emissions, the difference for particles with radius $r>0.5 \mu \mathrm{m}$ is very likely due to coarse volcanic particles. This result is consistent with measurements performed over Central Europe (e.g. Emeis et al., 2011; Petäjä et al., 2012). A drastic increase of particles with diameter greater than $1 \mu \mathrm{m}$ was observed at Augsburg, Germany, during the volcanic ash plume impact episode (Pitz et al., 2011). Moreover, size distribution measurements during aircraft flights over Central Europe also revealed the dominance of coarse particles to the total particulate mass in the volcanic ash plume (e.g. Schumann et al., 2011; Kristiansen et al., 2012).

\subsection{Surface in situ measurements}

Figure 7c shows the volume size distributions from TSIAPS (3321) measurements performed at the lidar site ( $\sim 10$ m a.s.l.) on 21 April at 14:49 and 16:11 UTC, respectively. Volume size distributions near the ground reach minimum values at a radius $r \cong 0.46 \mu \mathrm{m}$ and are characterized by a coarse mode peaking at $r \cong 1.4 \mu \mathrm{m}$, in satisfactory agreement to the AERONET-volume size distributions retrieved at 14:49 and 16:11 UTC, respectively (Fig. 7b). The volume concentration of both the column-integrated and the groundbased distribution was larger at 16:11 than at 14:49 UTC. Hence, the significant contribution of particles with radius 

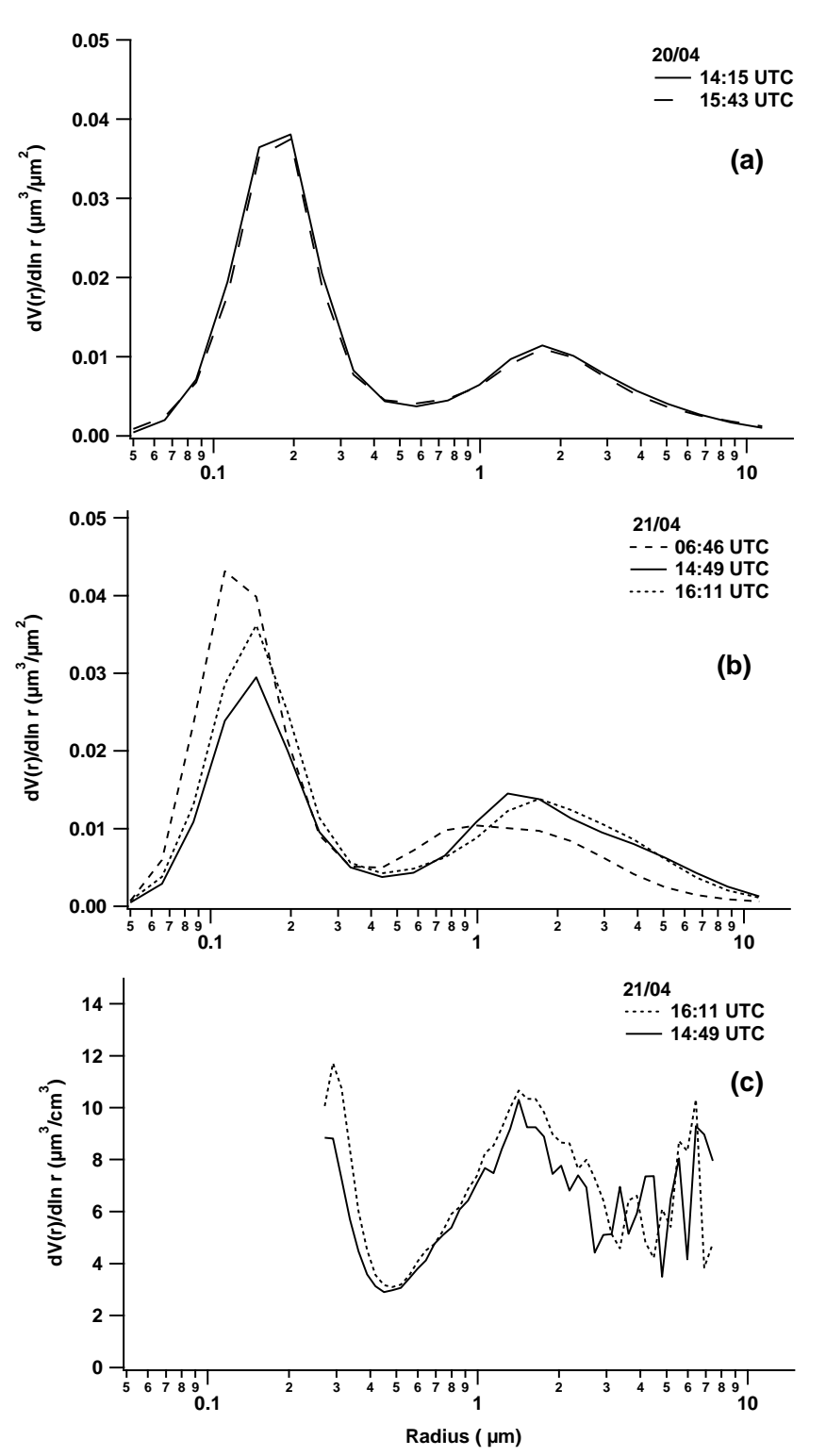

Fig. 7. Volume size distributions retrieved from AERONET sun/sky photometer measurements performed at different daytime hours of (a) 20 and (b) 21 April 2010. (c) Volume size distributions retrieved at the ground level from Aerodynamic Particle Sizer (APS 3321, TSI) measurements performed on 21 April 2010 at different daytime hours.

$r>1 \mu \mathrm{m}$ revealed by Fig. $7 \mathrm{c}$ was likely due to the impact of volcanic aerosol at ground. In situ measurements performed by Lettino et al. (2012) over southern Italy and by Rossini et al. (2012) over central Italy have also revealed the surface impact of volcanic particles with radius $r>1 \mu \mathrm{m}$.

$\mathrm{PM}_{1}$ (particles with an aerodynamic diameter $\leq 1 \mu \mathrm{m}$ ) and $\mathrm{PM}_{2.5}$ (particles with an aerodynamic diameter $\leq 2.5 \mu \mathrm{m}$ ) samples were also collected at the lidar site from 21 to 24 April. Mass concentrations of daily $\mathrm{PM}_{1}$ and $\mathrm{PM}_{2.5}$ samples revealed that the $\mathrm{PM}_{1} / \mathrm{PM}_{2.5}$ mass ratios were $0.69,0.66$, and

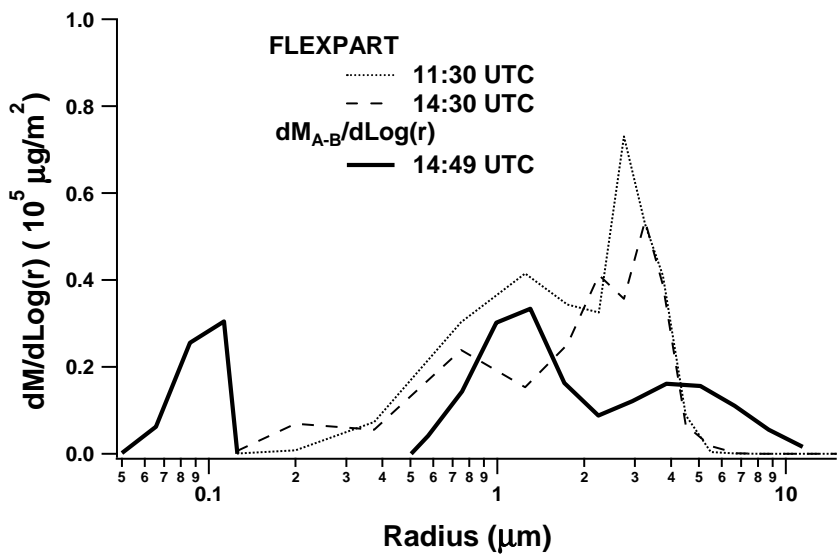

Fig. 8. Columnar mass size distribution of volcanic particles inferred from the AERONET volume size distribution retrieved at 14:49 UTC on 21 April, by setting the particle mass density for volcanic particles $\rho=3.0 \mathrm{~g} \mathrm{~cm}^{-3}$ (solid line). Columnar mass size distribution of volcanic ash from FLEXPART simulations at 11:30 UTC (dotted line) and 14:30 UTC (dashed line) on 21 April 2010.

0.60 on 20, 21, and 22 April, respectively, indicating that the contribution of particles with radius $>1 \mu \mathrm{m}$ increased from 21 to 22 April, in accordance with the daily evolution of the AERONET fine mode fraction.

Surface in situ $\mathrm{SO}_{2}$ and $\mathrm{PM}_{10}$ measurements performed by the Regional Air Quality Agency (http://www.arpa.puglia.it/ web/guest/qariainq) have been analyzed to infer the volcanic aerosol effects on regional scale. Enhanced $\mathrm{PM}_{10}$ and $\mathrm{SO}_{2}$ concentrations were monitored all over south-eastern Italy from 20 to 22 April 2010. Table 2 reports the daily $\mathrm{PM}_{10}$ mass concentrations monitored from 19 to 23 April 2010, at 10 sites of the $400 \mathrm{~km}$ long Apulia Region (Fig. 9), in addition to the average value (avg) over all sites. Uncertainties of $\mathrm{PM}_{10}$ values are smaller than $5 \%$. Yearly mean (Y-M) mass concentrations \pm 1 standard deviation (SD) and site type definition are also provided in the last two columns of Table 2. The largest $\mathrm{PM}_{10}$ mass concentrations were monitored on 21 April at all sites (within experimental uncertainties), with the exception of site $\mathrm{A}$, the site furthest in the north, where the largest $\mathrm{PM}_{10}$ level was reached on 20 April. These results suggest that the $\mathrm{PM}_{10}$ enhancement was very likely due to a large-scale pollution event, consistent with the arrival of volcanic particles (Sect. 3.1). $\mathrm{PM}_{10}$ levels larger than corresponding yearly-means were reached at most of the sites on 20 or 21 April. The inhomogeneous structure of the volcanic particle cloud was likely responsible for the variability of the $\mathrm{PM}_{10}$ enhancement found at different sites. Enhanced $\mathrm{PM}_{10}$ mass concentrations were found all over Europe when the volcanic ash cloud was present (e.g. Schäfer et al., 2011; Emeis et al., 2011). $\mathrm{PM}_{10}$ averaged values reported in Table 2 show that the mean $\mathrm{PM}_{10}$ mass concentrations in the Apulia region increased by 4,9 , and $5 \mu \mathrm{g} \mathrm{m}^{-3}$ (or by 22,50 , 
Table 2. $\mathrm{PM}_{10}$ mass concentrations $\left(\mu \mathrm{g} \mathrm{m}^{-3}\right.$ ) measured at different sites in the Apulia Region (shown in Fig. 9) from 19 to 23 April 2010. Yearly-mean (Y-M) mass concentrations \pm 1 standard deviation (SD) and site type definition are provided in the last two columns.

\begin{tabular}{cccccccl}
\hline Site & $\begin{array}{c}\text { 19 April } \\
\left(\mu \mathrm{g} \mathrm{m}^{-3}\right)\end{array}$ & $\begin{array}{c}20 \text { April } \\
\left(\mu \mathrm{g} \mathrm{m}^{-3}\right)\end{array}$ & $\begin{array}{c}21 \text { April } \\
\left(\mu \mathrm{g} \mathrm{m}^{-3}\right)\end{array}$ & $\begin{array}{c}22 \text { April } \\
\left(\mu \mathrm{g} \mathrm{m}^{-3}\right)\end{array}$ & $\begin{array}{c}23 \text { April } \\
\left(\mu \mathrm{g} \mathrm{m}^{-3}\right)\end{array}$ & $\begin{array}{l}\text { Y-M } \pm \text { SD } \\
\left(\mu \mathrm{g} \mathrm{m}^{-3}\right)\end{array}$ & $\begin{array}{l}\text { Site } \\
\text { Type }\end{array}$ \\
\hline A & 26 & 33 & 28 & 22 & 20 & $19 \pm 11$ & rural \\
B & 15 & 20 & 27 & 21 & 21 & $23 \pm 9$ & suburban \\
C & 23 & 23 & 44 & 26 & 36 & $29 \pm 18$ & suburban \\
D & 20 & 24 & 27 & 24 & 21 & $25 \pm 16$ & suburban \\
E & 18 & 21 & 24 & 24 & 20 & $16 \pm 14$ & suburban \\
F & 13 & 21 & 25 & 25 & 19 & $21 \pm 10$ & suburban \\
G & 12 & 17 & 25 & 20 & 20 & $20 \pm 12$ & rural \\
H & 18 & 19 & 24 & 25 & 22 & $25 \pm 13$ & suburban \\
I & 18 & 22 & 24 & 23 & 19 & $26 \pm 13$ & suburban \\
L & 15 & 18 & 20 & 20 & 19 & $23 \pm 15$ & suburban \\
\hline Avg & 18 & 22 & 27 & 23 & 22 & & \\
\hline
\end{tabular}

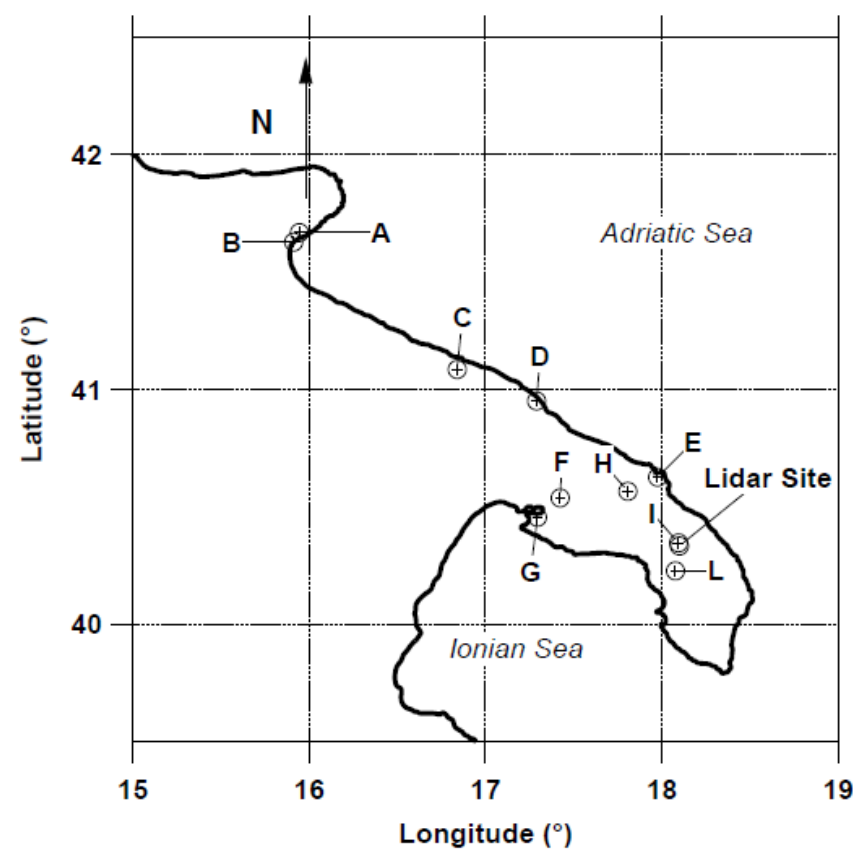

Fig. 9. Geographical locations of selected sites of the Air Quality Agency of the Apulia Region in south-eastern Italy and of the lidar site.

and $28 \%$ ) on 20, 21, and 22 April, respectively, relative to the mean $\mathrm{PM}_{10}$ level on 19 April. The $\mathrm{PM}_{10}$ enhancements at site I $(\sim 500 \mathrm{~m}$ away from the lidar site) were 4,6 , and $5 \mu \mathrm{g} \mathrm{m}^{-3}$ on 20,21 , and 22 April, respectively.

Figure 10 shows the time series of $\mathrm{PM}_{10}$ and $\mathrm{SO}_{2}$ mass concentrations at sites $\mathrm{G}$ and $\mathrm{C}$ (Fig. 9), which are approximately one hundred and two hundred kms away from the lidar site. The correlation between $\mathrm{PM}_{10}$ and $\mathrm{SO}_{2}$ mass concentrations, especially at site $\mathrm{C}$, is also suggestive of a volcanic source of the $\mathrm{PM}_{10}$ enhancements, since $\mathrm{SO}_{2}$ is

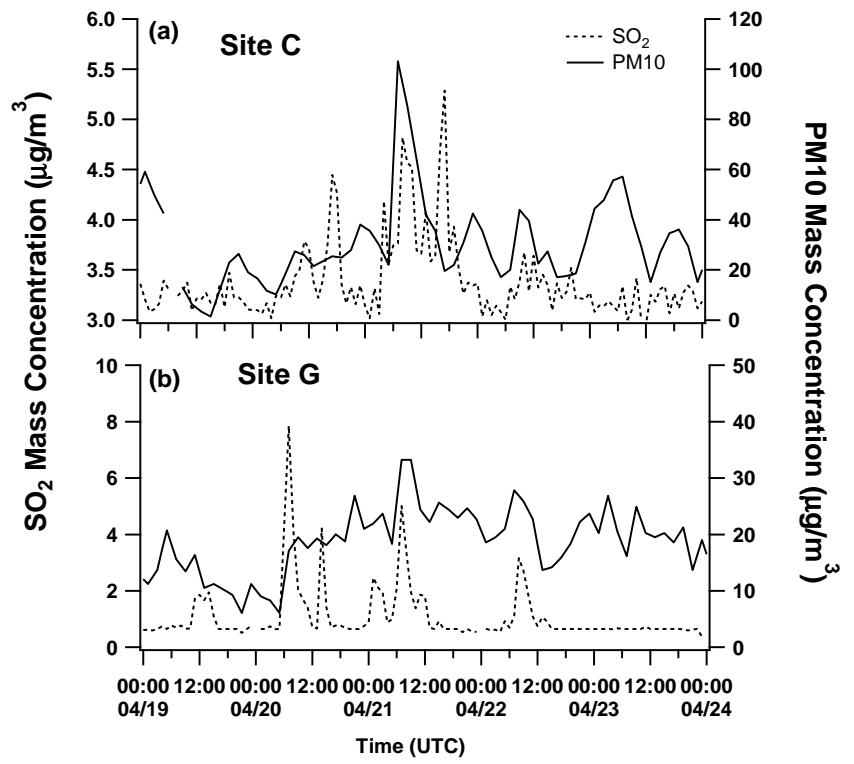

Fig. 10. Time series of $\mathrm{PM}_{10}$ and $\mathrm{SO}_{2}$ mass concentrations at sites $\mathrm{C}$ and $\mathrm{G}$ (locations are shown in Fig. 9).

also emitted by the volcano. Correlations between particulate matter and $\mathrm{SO}_{2}$ in the Eyjafjallajökull plume have been observed earlier both by aircraft (Schumann et al., 2011) as well as from the ground (e.g. Emeis et al., 2011). Figure 10b reveals that a fast increase of $\mathrm{PM}_{10}$ and $\mathrm{SO}_{2}$ mass concentrations occurred at $\sim$ 06:00 UTC on 20 April and that high peak $\mathrm{SO}_{2}$ mass concentrations were reached earlier at site $\mathrm{G}$ than at site $\mathrm{C}$, even though site $\mathrm{G}$ is further south than site $\mathrm{C}$. The advection over south-eastern Italy of an inhomogeneous cloud of volcanic particles was likely responsible for these results. Volcanic particles were detected at the CNR-IMAA Laboratory which is $\sim 150 \mathrm{~km}$ away from site $\mathrm{G}$, since the night of 19 April (Madonna et al., 2010; Mona et al., 2012) 
and back trajectory pathways reveal that the back trajectory ending on 20 April, 06:00 UTC at $100 \mathrm{~m}$ a.s.l. crossed the CNR IMAA Laboratory area before reaching site G.

\subsection{Measurements and FLEXPART simulations}

Experimental results are compared in this section with numerical results from the dispersion model FLEXPART to contribute to the validation of the model abilities at a distance of approximately $4000 \mathrm{~km}$ from the volcano site. Dotted lines in Fig. 3 represent one-hour average vertical profiles of the volcanic ash mass concentration at the lidar site from FLEXPART simulations. The comparison of solid and dotted lines in Fig. 3 reveals the ability of the model to catch, at least in some cases, main features of the aerosol vertical distribution retrieved from lidar measurements. One must be aware that volcanic ash mass concentration profiles from FLEXPART cannot be directly compared to lidar profiles, since FLEXPART profiles are only representative of volcanic ash particles, while non-volcanic particles have also contributed to the retrieved lidar profiles.

Notice that FLEXPART predicts the arrival of ash on 20 April, 17:30 UTC (Fig. 3b, dotted line) within the altitude range for which backscatter coefficient values (Fig. 3b, solid line) were ascribed to a larger contribution of volcanic particles, in accordance with the discussion reported in Sect. 3.2. Aerosol particles up to about $4 \mathrm{~km}$ have been detected by the lidar at 23:30 UTC on 20 April and the vertical structure of $\beta$ (Fig. 3c, solid line) and LR (Fig. 4b, full dots) have allowed inferring the presence of two aerosol layers, with the upper layer (2.1-3.3 km a.s.1.) characterized by larger LR values ( $64 \pm 5 \mathrm{sr}$ ) due to a larger contribution of volcanic particles (Ansmann et al., 2010). Accordingly, the FLEXPART profile at 23:30 UTC (Fig. 3c, dotted line) shows that a volcanic ash layer extends from $\sim 2 \mathrm{~km}$ up to $3.7 \mathrm{~km}$ a.s.l. The highest concentrations of about $170 \mu \mathrm{g} \mathrm{m}^{-3}$ at $\sim 3 \mathrm{~km}$ a.s.l. are about a factor of 7 lower than the highest values on 16 April over Leipzig. This suggests that the volcanic ash over south-eastern Italy was strongly diluted. Notice that on 16 April, Asmann et al. (2010) found from lidar measurements at $355 \mathrm{~nm}$ performed over Leipzig, that backscatter and extinction coefficients reached peak values of $7.5 \mathrm{Mm}^{-1} \mathrm{sr}^{-1}$ and $370 \mathrm{Mm}^{-1}$, respectively in the center of the ash plume. Figure 3c (solid line) and Fig. 4b (solid line) show that at 23:30 UTC on 20 April backscatter and extinction coefficients reached values up to $0.7 \mathrm{Mm}^{-1} \mathrm{sr}^{-1}$ and $30 \mathrm{Mm}^{-1}$, respectively, within 3-4 km a.s.l. We have assumed that the aerosol load located above $3 \mathrm{~km}$ from the ground was mainly due to volcanic aerosol. Hence, extinction and backscatter coefficients over Lecce in the volcanic aerosol layer were about a factor of 10 lower than the highest values monitored at Leipzig on 16 April. This is in reasonable accordance with FLEXPART ratios of peak ash mass concentrations at Leipzig (16 April) and Lecce (20 April).
Figure 3g (dotted line) shows that the simulated volcanic ash was mainly located from the ground up to $\sim 1.2 \mathrm{~km}$ and from 2 up to $\sim 3.7 \mathrm{~km}$ at 23:30 UTC on 21 April, in satisfactory accordance with lidar measurements which detected aerosol particles up to $\sim 3.7 \mathrm{~km}$ a.s.l. (Fig. $3 \mathrm{~g}$, solid line). Both the backscatter coefficient values (solid line) and the simulated volcanic ash mass concentrations (dotted line) were characterized by rather low values at 17:30 UTC on 22 April (Fig. 31), suggesting an end of the volcanic ash episode.

Figure 5 shows the time evolution from 20 to 22 April 2010 of the ash total column mass concentration from FLEXPART (Ma, full triangles) above the lidar site, in addition to the aerosol optical thickness at $355 \mathrm{~nm}$ (open dots) retrieved from lidar measurements. Ash total column mass concentration values vary significantly with time and reach rather low values after midday on 22 April. Accordingly, we have found that AOT values also were quite dependent on monitoring time and reached rather low values after midday on 22 April. Ma and AOT reach high peak values at different times. Uncertainties in the model simulations which grow as the ash cloud is transported far from its source and over complex topography (e.g., the Alps) (Kristiansen et al., 2012) are expected to lead to some discrepancies between the model and measurements for the diluted ash cloud over Southern Italy. Kristiansen et al. (2012) found a time delay between the modelled and measured $\mathrm{PM}_{10}$ peak values at the Jungfraujoch station (Swiss Alps). However, one must be aware that changes of the contribution by volcanic and non-volcanic particles have contributed to the variability with time of the AOT, while Ma was only due to volcanic ash.

The FLEXPART mass size distributions $(\mathrm{d} M / \mathrm{d} \log (r))$ for the monitoring site of this study are plotted in Fig. 11ac at different daytime hours of 20,21, and 22 April. Mass size distribution profiles of Fig. 11 represent 1-hour-average profiles. Please note that the $\mathrm{d} M / \mathrm{d} \log (\mathrm{r})$ data points of the 20 April profile at 23:30 UTC (Fig. 11a) must be multiplied by a factor of 2: volcanic ash mass concentrations reached the highest values on the night of 20 April over southeastern Italy. Figure 11 shows that modelled mass size distributions are dominated by particles with radius $r>1 \mu \mathrm{m}$. Dotted and dashed lines in Fig. 8 show for comparison the FLEXPART mass size distributions referring to $11: 30$ and 14:30 UTC, respectively, on 21 April. Hence, experimentally determined $\mathrm{d} M_{\mathrm{A}-\mathrm{B}} / \mathrm{d} \log (r)$ values are in reasonable agreement with FLEXPART mass size distributions, within the model expected uncertainties: both the experimentally determined and the FLEXPART size distributions reveal the significant contribution of particles within the $0.6-4 \mu \mathrm{m}$ radius range, even though peak values are reached at different radii. Again, one must be aware that FLEXPART particle size distributions cannot be directly compared to AERONET columnar volume size distributions, since non-volcanic particles as well as sulphate particles of volcanic origin may have contributed to the retrieved AERONET profiles. It is worth noting from Fig. 11 that the modeled mass size distributions for 


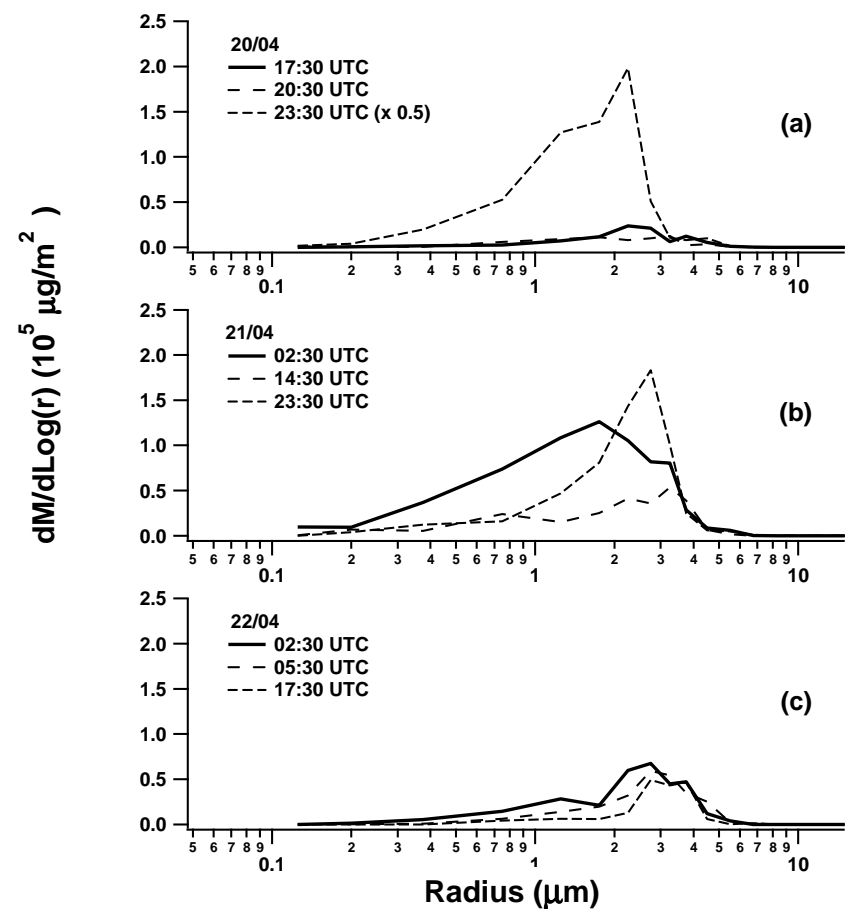

Fig. 11. Columnar mass size distribution of volcanic ash from FLEXPART simulations at different hours on (a) 20, (b) 21, and (c) 22 April 2010 .

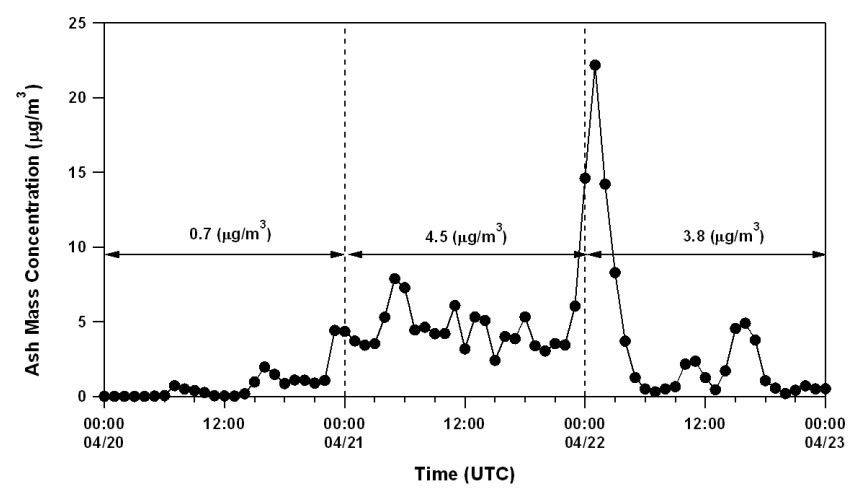

Fig. 12. Time evolution at the lidar site of the volcanic ash mass concentration $\left(\mu \mathrm{g} \mathrm{m}^{-3}\right)$ at $\sim 150 \mathrm{~m}$ a.s.l. from FLEXPART simulations. Daily means on 20, 21, and 22 April are also provided.

22 April (Fig. 11c) are shifted to larger particle sizes than the ones for 20 April (Fig. 11a). This result is in accordance with both the AERONET fine-mode-fraction means that decreased from 20 to 22 April (Fig. 6, open triangles) and the ground measurements of size segregated mass concentrations (Fig. 7c).

Figure 12 shows the time evolution of the volcanic ash mass concentrations $\left(\mu \mathrm{g} \mathrm{m}^{-3}\right)$ from FLEXPART simulations at the lidar site and at $\sim 150 \mathrm{~m}$ a.s.l. Daily means of the volcanic ash mass concentration are $0.7,4.5$, and $3.8 \mu \mathrm{g} \mathrm{m}^{-3}$ on 20, 21, and 22 April, respectively. These results are in rea- sonable accordance with the measurements at site I, which is only a few hundred meters away from the lidar site. There, the $\mathrm{PM}_{10}$ enhancements were 4,6 , and $5 \mu \mathrm{g} \mathrm{m}^{-3}$ on 20,21 , and 22 April, respectively (Table 2).

\section{Summary and conclusion}

Results on the characterization of aged volcanic aerosol by lidar, sun/sky photometer, and surface in-situ measurements at a south-eastern Italian site, which is approximately $4000 \mathrm{~km}$ away from the Eyjfjallajökull volcano, have been reported. Meteorological synoptic maps and analytical back trajectories have revealed that southern Italy was mainly affected by volcanic ash particles from 20 to 22 April 2010, in accordance with other published studies. However, the volcanic ash over southeastern Italy was strongly diluted. The extinction and backscatter coefficients retrieved in volcanic aerosol layers at Lecce were about a factor of 10 lower than the highest values monitored at Leipzig on 16 April. Lidar measurements performed at the Physics Department of the University of Salento within EARLINET showed that at 19:30 UTC on 20 April, volcanic particles were located near 2.1-3.3 km a.g.l. Mean lidar ratios (LRs) at $355 \mathrm{~nm}$ were $64 \pm 5 \mathrm{sr}$ inside the volcanic aerosol layer, but only about $47 \pm 2 \mathrm{sr}$ at lower altitudes. The dependence of LR values on altitude decreased with time mainly because of the high variability of the volcanic particle contributions. In fact, the vertical structure of the lidar backscatter coefficient and of the AOT at $355 \mathrm{~nm}$ varied significantly on 20, 21, and 22 April.

AERONET sun/sky photometer measurements revealed that volcanic particles with radius $r>0.5 \mu \mathrm{m}$ arrived over south-eastern Italy and that the contribution of coarse particles increased with time: the aerosol fine mode fraction varied from 0.85 to 0.94 on 20 April and from 0.25 to 0.82 on 22 April. Ground-level in-situ measurements of the aerosol size distribution were in satisfactory accordance with columnaraverage size distributions from sun/sky photometer measurements. Daily $\mathrm{PM}_{1}$ and $\mathrm{PM}_{2.5}$ mass concentrations showed that the $\mathrm{PM}_{1} / \mathrm{PM}_{2.5}$ ratio was $0.69,0.66$, and 0.60 on 20 , 21 , and 22 April, again suggesting the advection of volcanic particles with aerodynamic radius $r>0.5 \mu \mathrm{m}$, in accordance with AERONET sun/sky photometer measurements. Enhanced $\mathrm{PM}_{10}$ and $\mathrm{SO}_{2}$ concentrations were also found all over a $400 \mathrm{~km}$ long area of southern Italy from 20 to 22 April 2010. In particular, $\mathrm{PM}_{10}$ mass concentrations averaged over all measurements in the Apulia Region increased by $22 \%$, $50 \%$, and $28 \%$ on 20,21 , and 22 April, respectively, compared to values on 19 April.

The comparison of experimental measurements with numerical simulations by the FLEXPART dispersion model revealed that FLEXPART

- could capture the arrival of volcanic ash particles over south-eastern Italy from 20 to 22 April; 
- caught the high variability with altitude and time of volcanic particles advected $\sim 4000 \mathrm{~km}$ away from the volcano site;

- was able to model the size distribution of volcanic particles and the increase of average particle size with time;

- captured the enhancement of $\mathrm{PM}_{10}$ levels at our monitoring site.

In conclusion, the paper shows that the integrated use of different remote sensing and in situ sampling devices allow characterizing some optical and microphysical properties of aged volcanic particles even in a plume that was very dilute compared to the ash plume observed over Central Europe a few days earlier. The paper also contributes to the validation of the FLEXPART dispersion model. It is rather important to test advanced dispersion models to better evaluate in the future the hazard to aviation due to volcanic ash and, more generally, to better evaluate the impact of volcanic ash emissions on the environment.

Acknowledgements. The financial support of the EARLINETASOS Network by the European Commission under grant RICA-025991 is gratefully acknowledged. The authors would like to thank the NOAA Air Resource Laboratory for providing HYSPLIT back trajectories and the Regional Air Quality Agency of Apulia Region for provideng $\mathrm{PM}_{10}$ and $\mathrm{SO}_{2}$ data.

Edited by: C. Bay Hasager

\section{References}

Ansmann, A., Riebesell, M., Wandinger, U., Weitkamp, C., Voss, E., Lahmann, W., and Michaelis, W.: Combined Raman ElasticBackscatter LIDAR for Vertical Profiling of Moisture, Aerosol Extinction, Backscatter, and LIDAR Ratio, Appl. Phys., B55, 18-28, 1992.

Ansmann, A., Tesche, M., Gross, S., Freudenthaler, V., Seifery, P., Hiebsch, A., Schmidt, J., Wandinger, U., Mattis, I., and Wiegner, M.: The 16 April 2010 major volcanic ash plume over central Europe: EARLINET lidar and AERONET photometer observations at Leipzig and Munich, Germany, Geophys. Res. Lett., 37, L13810, doi:10.1029/2010GL043809, 2010.

Bevington, P. R. and Robinson, K. D.: Data reduction and error analysis for the physical sciences, 3rd Edn., Boston, MA, McGraw-Hill, ISBN 0-07-247227-8, 2003.

Bukowiecki, N., Zieger, P., Weingartner, E., Jurányi, Z., Gysel, M., Neininger, B., Schneider, B., Hueglin, C., Ulrich, A., Wichser, A., Henne, S., Brunner, D., Kaegi, R., Schwikowski, M., Tobler, L., Wienhold, F. G., Engel, I., Buchmann, B., Peter, T., and Baltensperger, U.: Ground-based and airborne in-situ measurements of the Eyjafjallajökull volcanic aerosol plume in Switzerland in spring 2010, Atmos. Chem. Phys., 11, 10011-10030, doi:10.5194/acp-11-10011-2011, 2011.

Campanelli, M., Estelles, V., Smyth, T., Tomasi, C., MartìnezLozano, M. P., Claxton, B., Muller, P., Pappalardo, G., Pietruczuk, A., Shanklin, J., Colwell, S., Wrench, C., Lupi, A.,
Mazzola, M., Lanconelli, C., Vitale, V., Congeduti, F., Dionisi, D., Cardillo, F., Cacciani, M., Casasanta, G., and Nakajima, T.: Monitoring of Eyjafjallajökull volcanic aerosol by the new European Skynet Radiometers (ESR) network, Atmos. Environ., 48, 33-45, doi:10.1016/j.atmosenv.2011.09.070, 2012.

De Tomasi, F. and Perrone, M. R.: Lidar measurements of tropospheric water vapor and aerosol profiles over south-eastern Italy, J. Geophys. Res., 108, 4286-4297, 2003.

De Tomasi, F. and Perrone, M. R.: PBL and dust layer seasonal evolution by lidar and radiosounding measurements over a peninsular site, Atmos. Res., 80, 86-103, 2006.

De Tomasi, F., Blanco, A., and Perrone, M. R.: Raman lidar monitoring of extinction and backscattering of African dust layer and dust characterization, Appl. Optics, 42, 1699-1709, 2003.

De Tomasi, F., Tafuro, A. M., and Perrone, M. R.: Height and seasonal dependence of aerosol optical properties over south-east Italy, J. Geophys. Res., 111, D10203, doi:10.1029/2005JD006779, 2006.

Draxler, R. R. and Rolph, G. D.: HYSPLIT (HYbrid Single-Particle Lagrangian Integrated Trajectory) Model access via NOAA ARL READY Website (http://ready.arl.noaa.gov/HYSPLIT. php), NOAA Air Resources Laboratory, Silver Spring, MD, 2010.

Dubovik, O. and King, M. D.: A flexible inversion algorithm for retrieval of aerosol optical properties from Sun and sky radiance measurements, J. Geophys. Res., 105, 20673-20696, doi:10.1029/2000JD900282, 2000.

Dubovik, O., Smirnov, A., Holben, B. N., King, M. D., Kaufman, Y. J., Eck, T. F., and Slutsker, I.: Accuracy assessments of aerosol optical properties retrieved from Aerosol Robotic Network (AERONET) Sun and sky radiance measurements, J. Geophys. Res., 105, 9791-9806, doi:10.1029/2000JD900040, 2000.

Emeis, S., Forkel, R., Junkermann, W., Schäfer, K., Flentje, H., Gilge, S., Fricke, W., Wiegner, M., Freudenthaler, V., Groß, S., Ries, L., Meinhardt, F., Birmili, W., Münkel, C., Obleitner, F., and Suppan, P.: Measurement and simulation of the 16/17 April 2010 Eyjafjallajökull volcanic ash layer dispersion in the northern Alpine region, Atmos. Chem. Phys., 11, 2689-2701, doi:10.5194/acp-11-2689-2011, 2011.

Folch, A., Costa, A., and Basart, S.: Validation of the FALL3D ash dispersion model using observations of the 2010 Eyjafjallajökull volcanic ash clouds, Atm. Env., 48, 165-183, doi:10.1016/j.atmosenv.2011.06.072, 2012.

Gasteiger, J., Groß, S., Freudenthaler, V., and Wiegner, M.: Volcanic ash from Iceland over Munich: mass concentration retrieved from ground-based remote sensing measurements, Atmos. Chem. Phys., 11, 2209-2223, doi:10.5194/acp-11-22092011, 2011.

Groß, S., Freudenthaler, V., Wiegner, M., Gasteiger, J., Geiß, A., and Schnell, F.: Dual-wavelength linear depolarization ratio of volcanic aerosols: lidar measurements of the Eyjafjallajökull plume over Maisach, Germany, Atmos. Environ., 48, 85-96, doi:10.1016/j.atmosenv.2011.06.017, 2011.

Heinold, B., Tegen, I., Wolke, R., Ansmann, A., Mattis, I., Minikin, A., Schumann, U., and Weinzierl, B.: Simulations of the 2010 Eyjafjallajökull volcanic ash dispersal over Europe using COSMO-MUSCAT, Atmos. Environ., 48, 195-204, 2012.

Holben, B. N., Eck, T. F., Slutsker, I., Tanré, D., Buis, J. P., Setzer, A., Vermote, E., Reagan, J. A., Kaufman, Y. J., Nakajima, 
T., Lavenu, F., Jankowiak, I., and Smirnov, A.: AERONET - A federate instrument network and data archive for aerosol characterization, Remote Sens. Environ., 66, 1-16, 1998.

Kristiansen, N. I., Stohl, A., Prata, A. J., Bukowiecki, N., Dacre, H., Eckhardt, S., Henne, S., Hort, M. C., Johnson, B. T., Marenco, F., Neininger, B., Reitebuch, O., Seibert, P., Thomson, D. J., Webster, H. N., and Weinzierl, B.: Performance assessment of a volcanic ash transport model mini-ensemble used for inverse modelling of the 2010 Eyjafjallajökull eruption, J. Geophys. Res., 117, D00U11, doi:10.1029/2011JD016844, 2012.

Langmann, B., Folch, A., Hensch, M., and Matthias, V.: Volcanic ash over Europe during the eruption of Eyjafjallajökull on Iceland, April-May 2010, Atmos. Environ., 48, 1-8, doi:10.1016/j.atmosenv.2011.03.054, 2012.

Lettino, A., Caggiano, R., Fiore, S., Macchiato, M., Sabia, S., and Trippetta, S.: Eyjafjallajökull volcanic ash in southern Italy, Atmos. Environ., 48, 97-103, doi:10.1016/j.atmosenv.2011.05.037, 2012.

Madonna, F., Amodeo, A., D’Amico, G., Mona, L., and Pappalardo G.: Observation of non-spherical ultragiant aerosol using a microwave radar, Geophys. Res. Lett., 37, L21814, doi:10.1029/2010GL044999, 2010.

Matthias, V., Freudenthaler, V., Amodeo, A., Balis, D., Boesenberg, J., Chaikovsky, A., Chourdakis, G., Comeron, A., Delaval, A., De Tomasi, F., Eixmann, R., Hagard, A., Komguem, L. , Kreipl, S., Matthey, R., Rizi, V., Rodrigues, J. A., Wandinger, U., and Wang, X.: Aerosol lidar intercomparison in the framework of the EARLINET project: 1. Instrument, Appl. Optics, 43, 961-976, 2004.

Mona, L., Amodeo, A., D’ Amico, G., Giunta, A., Madonna, F., and Pappalardo, G.: Multi-wavelength Raman lidar observations of the Eyjafjallajökull volcanic cloud over Potenza, southern Italy, Atmos. Chem. Phys., 12, 2229-2244, doi:10.5194/acp-12-22292012, 2012.

Papayannis, A., Mamouri, R. E., Amiridis, V., Giannakaki, E., Veselovskii, I., Kokkalis, P., Tsaknakis, G., Balis, D., Kristiansen, N. I., Stohl, A., Korenskiy, M., Allaakhverdiev, K., Huseyinoglu, M. F., and Baykara, T.: Optical properties and vertical extension of aged ash layers over Eastern Mediterranean as observed by Raman lidars during Eyjafjallajökull eruption, Atmos. Environ., 48, 56-65, 2012.

Petäjä, T., Laakso, L., Grönholm, T., Launiainen, S., EvelePeltoniemi, I., Virkkula, A., Leskinen, A., Backman, J., Manninen, H. E., Sipilä, M., Haapanala, S., Hämeri, K., Vanhala, E., Tuomi, T., Paatero, J., Aurela, M., Hakola, H., Makkonen, U., Hellén, H., Hillamo, R., Vira, J., Prank, M., Sofiev, M., SiitariKauppi, M., Laaksonen, A., Lehtinen, K. E. J., Kulmala, M., Viisanen, Y., and Kerminen, V.-M.: In-situ observations of Eyjafjallajökull ash particles by hot-air balloon, Atmos. Environ., 48, 104-112, doi:10.1016/j.atmosenv.2011.08.046, 2012.

Petersen, G. N.: A short meteorological overview of the Eyjafjallajökull eruption 14 April-23 May 2010, Weather, 65, 203-207, 2010.

Pitz, M., Gu, J., Soentgen, J., Peters, A., and Cyrys, J.: Particle size distribution factor as an indicator for the impact of the Eyjafjallajökull ash plume at ground level in Augsburg, Germany, Atmos. Chem. Phys., 11, 9367-9374, doi:10.5194/acp-11-93672011, 2011.
Revuelta, M. A., Sastre, M., Fernández, A. J., Martín, L., García, R., Gómez-Moreno, F. J., Artíñano, B., Pujadas, M., and Molero, F.: Characterization of the Eyjafjallajökull volcanic plume over the Iberian Peninsula by lidar remote sensing and ground-level data collection, Atmos. Environ., 48, 46-55, doi:10.1016/j.atmosenv.2011.05.033, 2012.

Rossini, P., Molinaroli, E., De Falco, G., Fiesoletti, F., Papa, S., Pari, E., Renzulli, A., Tentoni, P., Testoni, A., Valentini, L., and Matteucci, G.: April-May 2010 Eyjafjallajökull volcanic fallout over Rimini, Italy, Atmos. Environ., 48, 122-128, doi:10.1016/j.atmosenv.2011.05.018, 2012.

Schäfer, K., Thomas, W., Peters, A., Ries, L., Obleitner, F., Schnelle-Kreis, J., Birmili, W., Diemer, J., Fricke, W., Junkermann, W., Pitz, M., Emeis, S., Forkel, R., Suppan, P., Flentje, H., Gilge, S., Wichmann, H. E., Meinhardt, F., Zimmermann, R., Weinhold, K., Soentgen, J., Münkel, C., Freuer, C., and Cyrys, J.: Influences of the 2010 Eyjafjallajökull volcanic plume on air quality in the northern Alpine region, Atmos. Chem. Phys., 11, 8555-8575, doi:10.5194/acp-11-8555-2011, 2011.

Schumann, U., Weinzierl, B., Reitebuch, O., Schlager, H., Minikin, A., Forster, C., Baumann, R., Sailer, T., Graf, K., Mannstein, H., Voigt, C., Rahm, S., Simmet, R., Scheibe, M., Lichtenstern, M., Stock, P., Rüba, H., Schäuble, D., Tafferner, A., Rautenhaus, M., Gerz, T., Ziereis, H., Krautstrunk, M., Mallaun, C., Gayet, J.F., Lieke, K., Kandler, K., Ebert, M., Weinbruch, S., Stohl, A., Gasteiger, J., Groß, S., Freudenthaler, V., Wiegner, M., Ansmann, A., Tesche, M., Olafsson, H., and Sturm, K.: Airborne observations of the Eyjafjalla volcano ash cloud over Europe during air space closure in April and May 2010, Atmos. Chem. Phys., 11, 2245-2279, doi:10.5194/acp-11-2245-2011, 2011.

Smirnov, A., Holben, B. N., Eck, T. F., Dubovik, O., and Slutsker, I.: Cloud screening and quality control algorithms for the AERONET database, Remote Sens. Environ., 73, 337-349, 2000.

Stohl, A.: Computation, accuracy and application of trajectories-a review and bibliography. Atmos. Environ., 32, 947-966, 1998.

Stohl, A., Forster, C., Frank, A., Seibert, P., and Wotawa, G.: Technical note: The Lagrangian particle dispersion model FLEXPART version 6.2, Atmos. Chem. Phys., 5, 2461-2474, doi:10.5194/acp-5-2461-2005, 2005.

Stohl, A., Prata, A. J., Eckhardt, S., Clarisse, L., Durant, A., Henne, S., Kristiansen, N. I., Minikin, A., Schumann, U., Seibert, P., Stebel, K., Thomas, H. E., Thorsteinsson, T., Tørseth, K., and Weinzierl, B.: Determination of time- and height-resolved volcanic ash emissions and their use for quantitative ash dispersion modeling: the 2010 Eyjafjallajökull eruption, Atmos. Chem. Phys., 11, 4333-4351, doi:10.5194/acp-11-4333-2011, 2011.

Toledano, C., Bennouna, Y., Cachorro, V., Ortiz de Galisteo, J. P., Stohl, A., Stebel, K., Kristiansen, N. I., Olmo, F. J., Lyamani, H., Obregón, M. A., Estellés, V., Wagner, F., Baldasano, J. M., González-Castanedo, V, Clarisse, L., and de Frutos, A. M.: Aerosol properties of the Eyjafjallajökull ash derived from sun photometer and satellite observations over the Iberian Peninsula, Atmos. Environ., 48, 22-32, doi:10.1016/j.atmosenv.2011.09.072, 2012.

Wiegner, M., Gasteiger, J., Groß, S., Schnell, F., Freudenthaler, V., and Forkel, R.: Characterization of the Eyjafjallajökull ashplume: Potential of lidar remote sensing, Phys. Chem. Earth, 4546, 79-86, doi:10.1016/j.pce.2011.01.006, 2012. 